EBR-II BLANKET FUEL LEACHING TEST USING SIMULATED J-13 WELL WATER

by

Jacqueline E. Fonnesbeck

Engineering Division

Argonne National Laboratory - West

P. O. Box 2528

Idaho Falls, ID 83403-2528

April 2000

ANL-99/13 


\section{DISCLAIMER}

This report was prepared as an account of work sponsored by an agency of the United States Government. Neither the United States Government nor any agency thereof, nor any of their employees, make any warranty, express or implied, or assumes any legal liability or responsibility for the accuracy, completeness, or usefulness of any information, apparatus, product, or process disclosed, or represents that its use would not infringe privately owned rights. Reference herein to any specific commercial product, process, or service by trade name, trademark, manufacturer, or otherwise does not necessarily constitute or imply its endorsement, recommendation, or favoring by the United States Government or any agency thereof. The views and opinions of authors expressed herein do not necessarily state or reflect those of the United States Government or any agency thereof. 


\section{DISCLAIMER}

Portions of this document may be illegible in electronic image products. Images are produced from the best available original document. 
Page

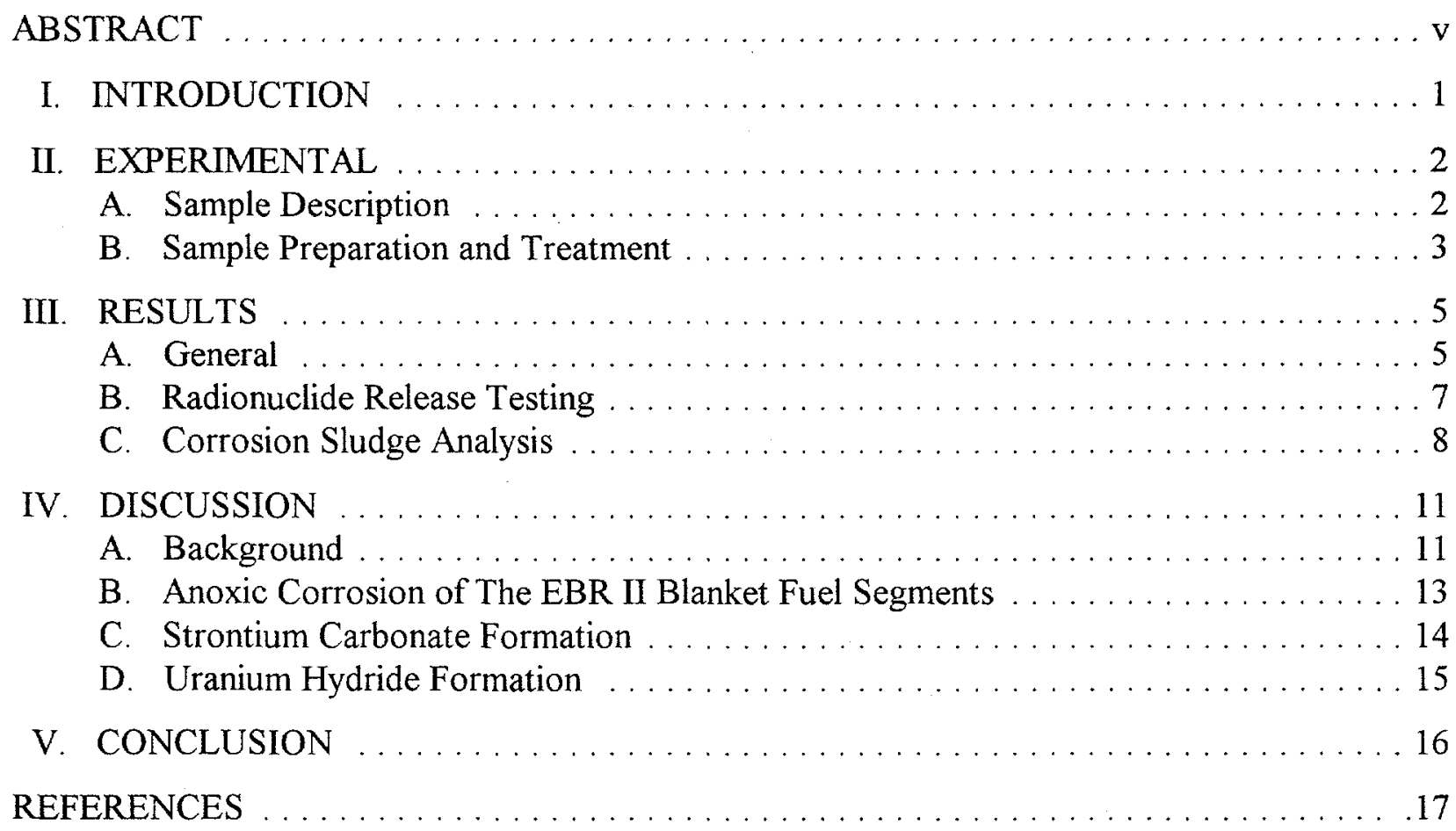




\section{LIST OF FIGURES}

Page

Figure 1. Superimposed Normalized Mass Loss Curves of ${ }^{137} \mathrm{Cs}$ for the Three EBR-II Blanket Fuel Segments

Figure 2. Superimposed Normalized Mass Loss Curves of ${ }^{90} \mathrm{Sr}$ for the Three EBR-II Blanket Fuel Segments 6

Figure 3. Superimposed XRD Patterns for the Three EBR-II Blanket Fuel Segments.

* indicates the presence of $\mathrm{UO}_{2}$ and + indicates the presence of $\mathrm{UH}_{3}$. The patterns for $\mathrm{F}-144[\mathrm{II}]$ and $\mathrm{F}-152[\mathrm{U}]$ show that $\mathrm{UH}_{3}$ is present $\ldots \ldots \ldots \ldots 9$

Figure 4. Back-Scattered Electron Image of F-152[U] Corrosion Sludge . . . . . . . . . . . . . 10

Figure 5. Energy Dispersive X-ray Spectrum of the Corrosion Sludge Belonging to F-152[U]. Uranium and oxygen peaks can be seen. The graphite coating contributes the carbon peak

Figure 6. Cs Dissolution Rate Curves for F-144 [I], F-144 [II], and F-152 [U] . . . . . . . . . 14

\section{LIST OF TABLES}

Page

Table 1. Physical Information for The Blanket Fuel Segments $\ldots \ldots \ldots \ldots \ldots \ldots \ldots 2$

Table 2. Chemical Additives for SJ-13 Well Water. De-ionized water was used as the solvent . . . . . . . . . . . . . . . . . . . . . . . . 4

Table 3. Mass Loss Data Table for ${ }^{90} \mathrm{Sr}$ and ${ }^{137} \mathrm{Cs} \ldots \ldots \ldots \ldots \ldots \ldots \ldots \ldots$

Table 4. X-Ray Diffraction Data Table for EBR-II Blanket Fuel Corrosion Sludge . . . . . . . 10

Table 5. Strontium and Carbonate Ion Mass Balance Data . . . . . . . . . . . . . . . . . . 15 


\title{
EBR-II BLANKET FUEL LEACHING TEST \\ USING SIMULATED J-13 WELL WATER
}

by

Jacqueline E. Fonnesbeck

\begin{abstract}
This paper discusses the results of a pulsed-flow leaching test using simulated J-13 well water leachant. This test was performed on three blanket fuel segments from the ANL-W EBR-II nuclear reactor which were originally made up of depleted uranium (DU). This experiment was designed to mimic conditions which would exist if, upon disposal of this material in a geological repository, it came in direct contact with groundwater. These segments were contained in pressure vessels and maintained at a constant temperature of $90^{\circ} \mathrm{C}$. Weekly aliquots of leachate were taken from the three vessels and replaced with an equal volume of fresh leachant. These weekly aliquots were analyzed for both ${ }^{90} \mathrm{Sr}$ and ${ }^{137} \mathrm{Cs}$. The results of the pulsed-flow leach test showed the formation of uranium oxide $\left(\mathrm{UO}_{2}\right)$ and uranium hydride $\left(\mathrm{UH}_{3}\right)$ particulate with rapid release of the ${ }^{137} \mathrm{Cs}$ and ${ }^{90} \mathrm{Sr}$ to the leachant. On the fifth week of sampling, one of the vessels became over pressurized and vented gas when opened. The most reasonable explanation for the presence of gas in this vessel is that the unoxidized uranium metal in the blanket segment could have reacted with the surrounding water leachant to form hydrogen. However, an investigation is currently being undertaken to both qualify and quantify $\mathrm{H}_{2}$ formation during uranium spent nuclear fuel corrosion in water.
\end{abstract}




\section{INTRODUCTION}

The primary objective of this experiment was to evaluate the interaction of irradiated blanket fuel from the Experimental Breeder Reactor II (EBR-II) at Argonne National LaboratoryWest (ANL-W) with simulated J-13 (SJ-13) well water at $90^{\circ} \mathrm{C}$. The incentive to perform this type of analysis originates from the fact that spent nuclear fuel and other high level radioactive waste is expected to be stored in geological repositories for indefinite periods of time. Over these prolonged periods, the containers used for the waste storage, Engineered Barrier Systems (EBS), will eventually lose their structural integrity and fail. In this event, any groundwater present could infiltrate the storage containers and interact with the spent fuel. The more soluble radioactive species in the waste fuel could then be transported in the groundwater to regions that, for instance, contain potable water. This scenario creates an incentive to study the dissolution kinetics of spent nuclear fuel in contact with surrogate groundwater as it provides us with valuable information on this type of interaction. [1]

The three EBR-II blanket fuel segments that were used in this experiment originated from subassembly U1302, element 10 . They included pin segments designated as follows: F-152 [U], and F-144 [I] \& [II]. The blanket element was originally made of unalloyed uranium metal, depleted in ${ }^{235} \mathrm{U}$. However, due to the fact that this blanket pin was irradiated over a span of thirty years, its final composition consisted roughly of $99 \%{ }^{238} \mathrm{U}, 1 \%{ }^{239} \mathrm{Pu}$ and some fission products and other transuranic elements.

The mode of measuring the dissolution rates of nuclides from these blanket fuels was adapted from a well-developed test method. [2,3,4,5] This method is commonly known as a pulsed-flow test which allows evaluation of the durability of radioactive materials when they come in contact with various solutions. Since this test method is fundamentally utilized to determine the leaching behavior of glass nuclear waste forms $[2,3,4,5,6]$, the contact solutions will from now on be referred to as leachants. Briefly, this test requires that the small volume of leachate used for analysis be relaced with fresh leachant. This process is supposed to mimic slow-flow groundwater 
conditions that could exist in geological repositories.

\section{EXPERIMENTAL}

\section{A. Sample Description}

The three cylindrical fuel segments chosen for this experiment originated from a $55^{\prime \prime}$ long blanket fuel pin. Without cladding, the diameter of each measured $0.433 "$. Table 1 provides more physical information for each segment. Included is the axial position of the segment relative to its distance from the bottom of the pin, its mass, its actual length, and the initial activities of both ${ }^{90} \mathrm{Sr}$ and ${ }^{137} \mathrm{Cs}$ per gram of sample.

The specific ${ }^{137} \mathrm{Cs}$ activity for each sample was estimated by extrapolating between samples of measured activity. Isotopic analysis had been previously performed on other segments of the same blanket pin to derive isotopic distributions of various fission products. This work was performed by the Analytical Laboratory (AL) at ANL-W.

As for ${ }^{90} \mathrm{Sr}$, no experimental data was available. The initial ${ }^{90} \mathrm{Sr}$ activity of each segment was based upon values taken from calculations made by Dick McKnight at ANL-E. These calculations were made with the assumption that the average segment length was $0.25 "$.

Table 1. Physical Information for The Blanket Fuel Segments

\begin{tabular}{|c|c|c|c|c|c|}
\hline $\begin{array}{c}\text { Segment ID } \\
\#\end{array}$ & $\begin{array}{c}\text { Segment } \\
\text { Location } \\
\text { from } \\
\text { bottom of } \\
\text { Pin (inches) }\end{array}$ & $\begin{array}{c}\text { Mass of } \\
\text { Segment } \\
\text { (grams) }\end{array}$ & $\begin{array}{c}\text { Length } \\
\text { of } \\
\text { Segment } \\
\text { (inches) }\end{array}$ & $\begin{array}{c}\text { Initial } \\
\text { Activity } \\
\text { of }{ }^{90} \mathrm{Sr} \\
(\mu \mathrm{Ci} / g)\end{array}$ & $\begin{array}{c}\text { Initial } \\
\text { Activity } \\
\text { of }{ }^{137} \mathrm{Cs} \\
(\mu \mathrm{Ci} / \mathrm{g})\end{array}$ \\
\hline F-152[U] & 35.50 & 8.5 & 0.185 & 2052.0 & 4078.4 \\
F-144 [I] & 30.00 & 3.6 & 0.086 & 2707.9 & 4784.5 \\
F-144 [II] & 30.25 & 14.3 & 0.331 & 2615.5 & 4768.7 \\
\hline
\end{tabular}


Therefore, corrections were made for the disparities between calculated and 'true' segment lengths. From these corrections, ${ }^{90} \mathrm{Sr}$ activities were derived. This data is shown in Table 1 column 5. It should be noted here that all activities were decay corrected to the first day of the experiment.

The initial activities of both ${ }^{137} \mathrm{Cs}$ and ${ }^{90} \mathrm{Sr}$ were converted to grams and these values were used to calculate the mass fraction, $f_{i}$, of these species. The mass fraction is simply defined as the mass of an element in an unleached sample divided by the mass of the sample. The mass fraction was eventually used to calculate the weekly loss of ${ }^{137} \mathrm{Cs}$ and ${ }^{90} \mathrm{Sr}$ from the sample. This is called the Normalized Elemental Mass Loss (NML) and will be discussed in further detail below.

\section{B. Sample Preparation and Treatment}

The samples were cut and stored in dry argon prior to receipt. When the containers were opened, the samples were promptly removed from their cladding, washed of any trace sodium using de-ionized water, dried, and weighed. The sodium had been present to provide a thermal bond between the fuel pin and the cladding. It should be noted here that, when freshly exposed to the air atmosphere of the ANL-W Analytical Laboratory Hot Cells, the color of each sample was grey indicating some surface oxidation of uranium had already occurred.

After weighing the samples, their dimensions were measured with a caliper. The geometry of a cylinder was used as the model to calculate the three sample surface areas. When measuring sample F-144 [II], a small fissure could be seen along the length. This added surface area was impossible to measure, therefore it was not added into the surface area calculation. When the surface areas of all three samples had been determined, the sample surface area-to-leachant volume ratio, $\mathrm{S} / \mathrm{V}$, for all three vessels could now be established which was $25 \mathrm{~m}^{-1}$.

The samples were then placed in standard $22 \mathrm{~mL} \mathrm{304L} \mathrm{stainless} \mathrm{steel} \mathrm{(Parr} \mathrm{Co.)} \mathrm{pressure}$ vessels. Placed within each vessel was a perforated titanium stand which prevented the sample from coming in direct contact with the bottom of the vessel. This ensured that most of the sample surface area would be exposed to the SJ-13 leachant at all times. The appropriate volumes of 
SJ-13 well water were then pipetted in with the corresponding samples. A blank of SJ-13 water was also prepared to maintain analytical integrity of the experiment. Weekly aliquots of the blank were also taken so that any chemistry performed on the sample leachates were simultaneously performed on the blanks to determine a base-line for contamination. Table 2 shows the chemical make-up of the simulated $J-13$ well water.

The vessels containing the samples and blank were capped and placed in an oven to be maintained at $90^{\circ} \mathrm{C}$ for the duration of the experiment and removed from the oven only for the brief time periods required for sampling. As stated above, the pulse flow method requires that a fraction of the leachate be removed at fixed time intervals and replaced with fresh leachant. Thus, $5 \mathrm{~mL}$ aliquots of leachate were taken out every 7 days for analysis and replaced with an additional $5 \mathrm{~mL}$ of fresh leachant. The samples were always filtered with a $0.45 \mu \mathrm{m}$ syringe filter.

One milliliter of the weekly leachate sample was used for ${ }^{137} \mathrm{Cs}$ gamma analysis. This $1 \mathrm{~mL}$ leachate sample aliquot was diluted up to fifty $\mathrm{mL}$ in a snap-cap vial and counted over a calibrated germanium lithium drifted (GeLi) detector. Upon completion of the ${ }^{137} \mathrm{Cs}$ gamma analysis $3 \mathrm{~mL}$

Table 2. Chemical Additives for SJ-13 Well Water De-ionized water was used as the solvent.

\begin{tabular}{|l|c|}
\hline Compound & Concentration, mg/L \\
\hline \hline $\mathrm{NaHCO}_{3}$ & 180 \\
$\mathrm{KHCO}_{3}$ & 14 \\
$\mathrm{CaCl}_{2} \cdot 2 \mathrm{H}_{2} \mathrm{O}$ & 14 \\
$\mathrm{Ca}\left(\mathrm{NO}_{3}\right)_{2} \cdot 4 \mathrm{H}_{2} \mathrm{O}$ & 19 \\
$\mathrm{CaSO}_{4} \cdot 2 \mathrm{H}_{2} \mathrm{O}$ & 20 \\
$\mathrm{MgSO}_{4} \cdot 7 \mathrm{H}_{2} \mathrm{O}$ & 18 \\
$\mathrm{SiO}_{2} \cdot \mathrm{H}_{2} \mathrm{O}$ & 84 \\
\hline
\end{tabular}

of this dilution was used to chemically separate strontium. Once separated, the ${ }^{90} \mathrm{Sr}$ was quantified via liquid scintillation counting. 
The raw data obtained from both ${ }^{90} \mathrm{Sr}$ and ${ }^{137} \mathrm{Cs}$ analysis was used to calculate the mass of both isotopes that was lost from the original blanket segment over time. This quantity was expressed as a Normalized Elemental Mass Loss $(N M L)[5]$ in the form of the following equation:

$$
(N M L)_{i}=m_{i} /\left(f_{i} \cdot S A\right)
$$

where:

$m_{i}=$ mass of element $i$ in the leachate in grams,

$f_{i}=$ mass fraction of element $i$ in the unleached sample, and

$S A=$ sample surface area, $\mathrm{m}^{2}$.

The final units of measurement for the $N M L$ were expressed in $\mathrm{g} / \mathrm{m}^{2}$.

\section{RESULTS}

\section{A. General}

As discussed above, weekly samples of leachate were taken from each vessel for isotopic analysis. This process was carried out over 133 days ( 19 weeks). For this time period, the $N M L$ s of both ${ }^{137} \mathrm{Cs}$ and ${ }^{90} \mathrm{Sr}$ were graphed for the three samples and are shown in the superimposed plots of Figures 1 and 2. 


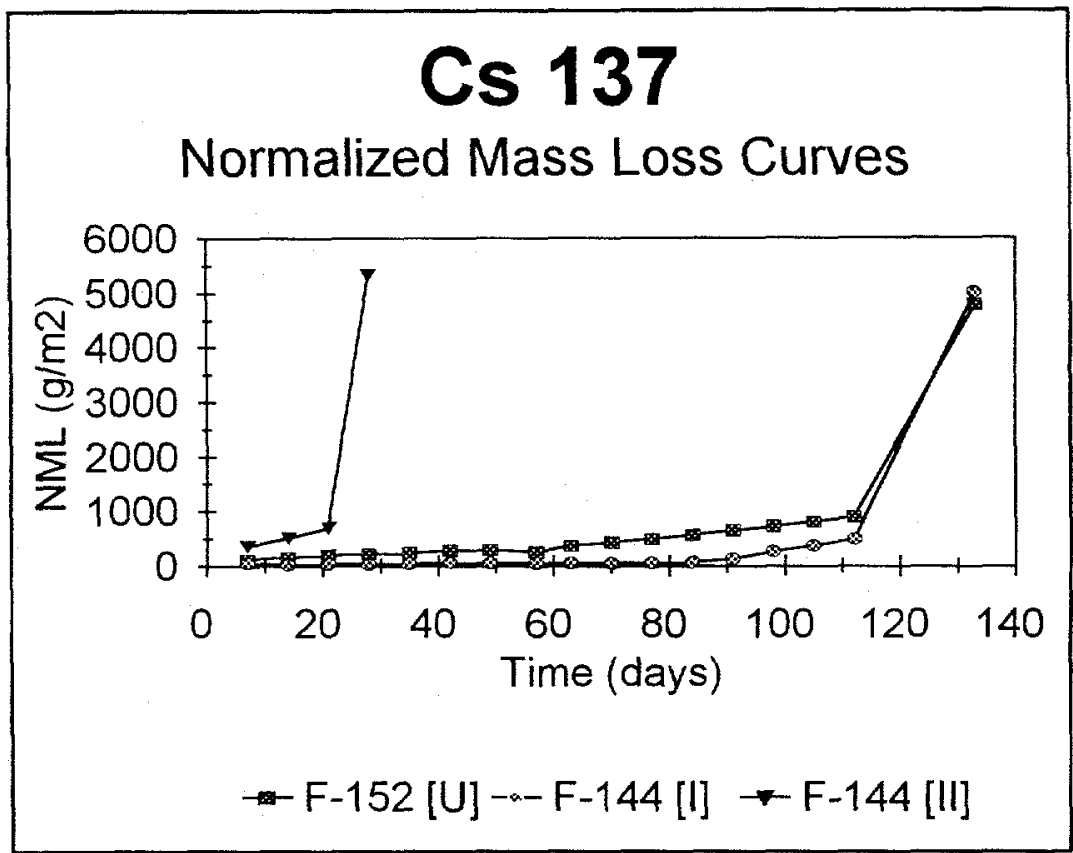

Figure 1. Normalized mass Loss Curves of ${ }^{137} \mathrm{Cs}$ for the Three EBR-II Blanket fuel Segments.

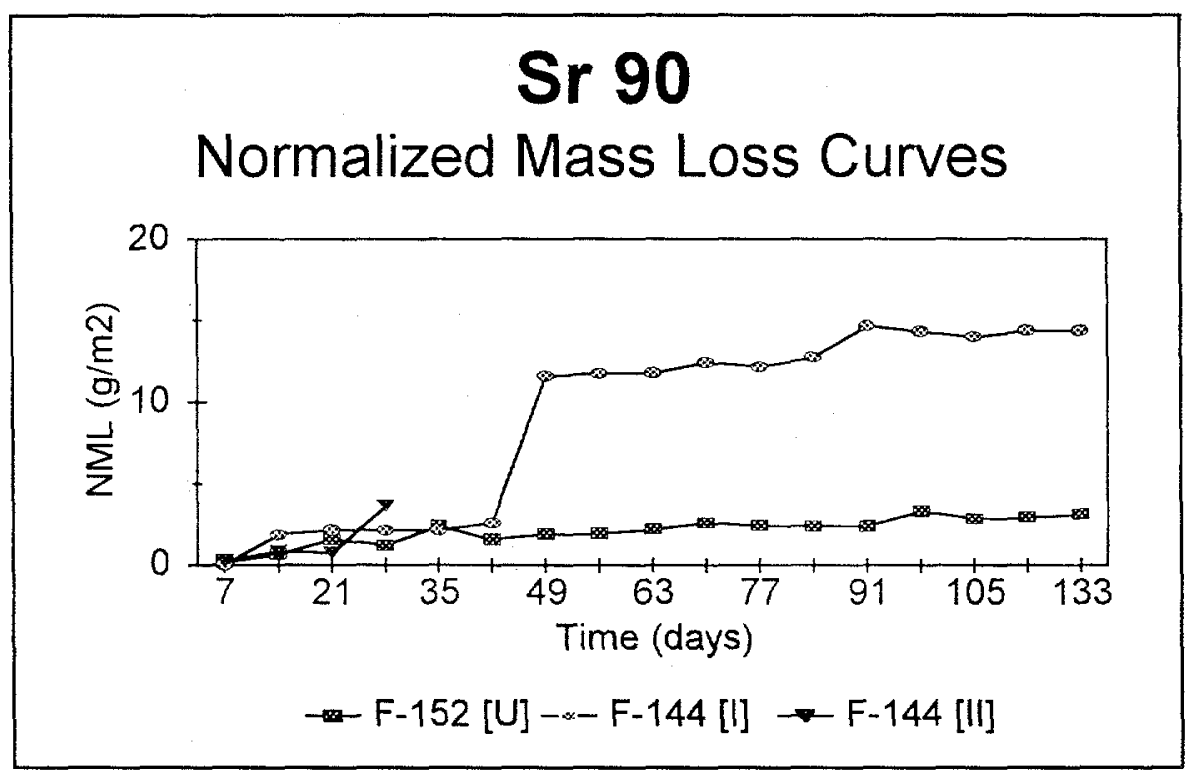

Figure 2. Superimposed Normalized mass Loss Curves of ${ }^{90} \mathrm{Sr}$ for the Three EBR-II Blanket Fuel Segments. 


\section{B. Radionuclide Release Testing}

During the first three weeks of testing, the $N M L$ curves for the three samples in Figures 1 and 2 exhibit moderate release rates. On the fourth week of sampling ( 28 days), a sudden upward trend in both the ${ }^{137} \mathrm{Cs}$ and ${ }^{90} \mathrm{Sr}$ curves for sample F-144 [II] was observed. This shift was an order of magnitude greater than that of the previous week.

On the fifth week of sampling ( 35 days), when opening the vessel containing segment F-144 [II], there was a vigorous release of gas and loss of leachate as the gas bubbled out of the vessel. Due to the high pressure buildup in the vessel, it was initially difficult to loosen the lid. The other sample vessels opened without any difficulty and without any obvious release of gas. The samples were then examined for any visible corrosion. Samples F-152 [U] and F-144 [I] exhibited visible corrosion. Not only were these samples covered with a layer of black powder, a fine film of this material coated the bottom of the vessel as well.

Sample F-144 [II] showed severe corrosion. In addition, the lid and upper head space of the vessel above the liquid level was also coated with a layer of the black powder. For practical purposes, the black powder (corrosion product) will now be referred to as "sludge".

Due to the unknown variables that changed the character of the leaching experiment involving sample F-144[II], any further sampling of the leachate from the F-144[II] vessel was stopped at this time. The vessel was then capped and set aside for future analysis of the corrosion sludge using X-Ray Powder Diffraction (XRD) and Scanning Electron Microscopy (SEM). Those results are presented below in section $\mathrm{C}$.

Routine sampling of the remaining two blanket segments continued. The contents of both vessels were viewed during weekly sampling intervals. The amount of corrosion sludge appeared to increase with each ensuing week. However, the metal segments appeared to be intact until the $16^{\text {th }}$ week (112 days) of sampling. After the $16^{\text {th }}$ week the segments were left in the oven,

unopened, for three weeks and then sampled again on the $19^{\text {th }}$ week (116 days). Figure 1 shows a dramatic increase of ${ }^{137} \mathrm{Cs}$ on the $19^{\text {th }}$ week. However, Figure 2 does not show the same increase 
of ${ }^{90} \mathrm{Sr}$. At the end of the leach test, the remaining two vessels were opened and the material inside was observed. As for sample F-152 [U], some of the original monolith remained intact, yet most had corroded to sludge. F-144 [I] had completely corroded into the black sludge. There was no trace of the original blanket segment. Interestingly enough, the amount of ${ }^{90} \mathrm{Sr}$ released from this sample jumped by an order of magnitude at week 7 (49 days). Yet after this, there was again a more gradual release of ${ }^{90} \mathrm{Sr}$ until the final sampling on week 19 . However, relative to the $N M L$ of ${ }^{137} \mathrm{Cs}$, this was still very little in comparison. The total mass loss of both ${ }^{137} \mathrm{Cs}$ and ${ }^{90} \mathrm{Sr}$ was calculated for the three blanket segments and the results are shown in Table 3.

Table 3 lists the leaching time, the mass of original monolith, the leachant volume, and the estimated percent mass loss of ${ }^{137} \mathrm{Cs}$ and ${ }^{90} \mathrm{Sr}$ from each of the three blanket segments a the end of the test. Notice that the percent of total ${ }^{137} \mathrm{Cs}$ leached from each segment was much greater than the percent of total ${ }^{90} \mathrm{Sr}$. It can also be seen that more cesium and strontium leached out of sample F-144 [I] than out of the other two samples. Remember that this particular blanket segment had entirely corroded during the intervening time between $16^{\text {th }}$ and the $19^{\text {th }}$ week of sampling.

Table 3. Mass Loss Data Table for ${ }^{90} \mathrm{Sr}$ and ${ }^{137} \mathrm{Cs}$

\begin{tabular}{||c|c|c|c|c|c|c||}
\hline \multirow{2}{*}{$\begin{array}{c}\text { Segment } \\
\text { ID }\end{array}$} & $\begin{array}{c}\text { Elapsed } \\
\text { Leaching } \\
\text { Time } \\
\text { (days) }\end{array}$ & $\begin{array}{c}\text { Mass of } \\
\text { Original } \\
\text { Monolith } \\
\text { (grams) }\end{array}$ & $\begin{array}{c}\text { Surface } \\
\text { Area of } \\
\text { Monolith } \\
\left(10^{-4} \mathrm{~m}^{2}\right)\end{array}$ & $\begin{array}{c}\text { Leachant } \\
\text { Volume } \\
(\mathrm{mL})\end{array}$ & \multicolumn{2}{|c|}{$\begin{array}{c}\text { Estimated Percent } \\
\text { Mass Loss }\end{array}$} \\
\hline \hline F-152[U] & 133 & 8.5 & 3.55 & 14.3 & 0.01 & 20.1 \\
F-144[I] & 133 & 3.6 & 2.70 & 10.9 & 0.11 & 37.3 \\
F-144[II] & 28 & 14.3 & 4.86 & 19.6 & 0.01 & 18.1 \\
\hline
\end{tabular}

F-144[I] was completely corroded at the end of the leaching period.

\section{Corrosion Sludge Analysis}

Sludge samples of the three blanket segments were rinsed, transported out of the hot-cell environment, and air-dried for analysis by X-Ray Diffraction (XRD). Figure 3 shows the superimposed XRD patterns. One can see that both $\mathrm{UO}_{2}$ and $\mathrm{UH}_{3}$ coexist within two out of the 


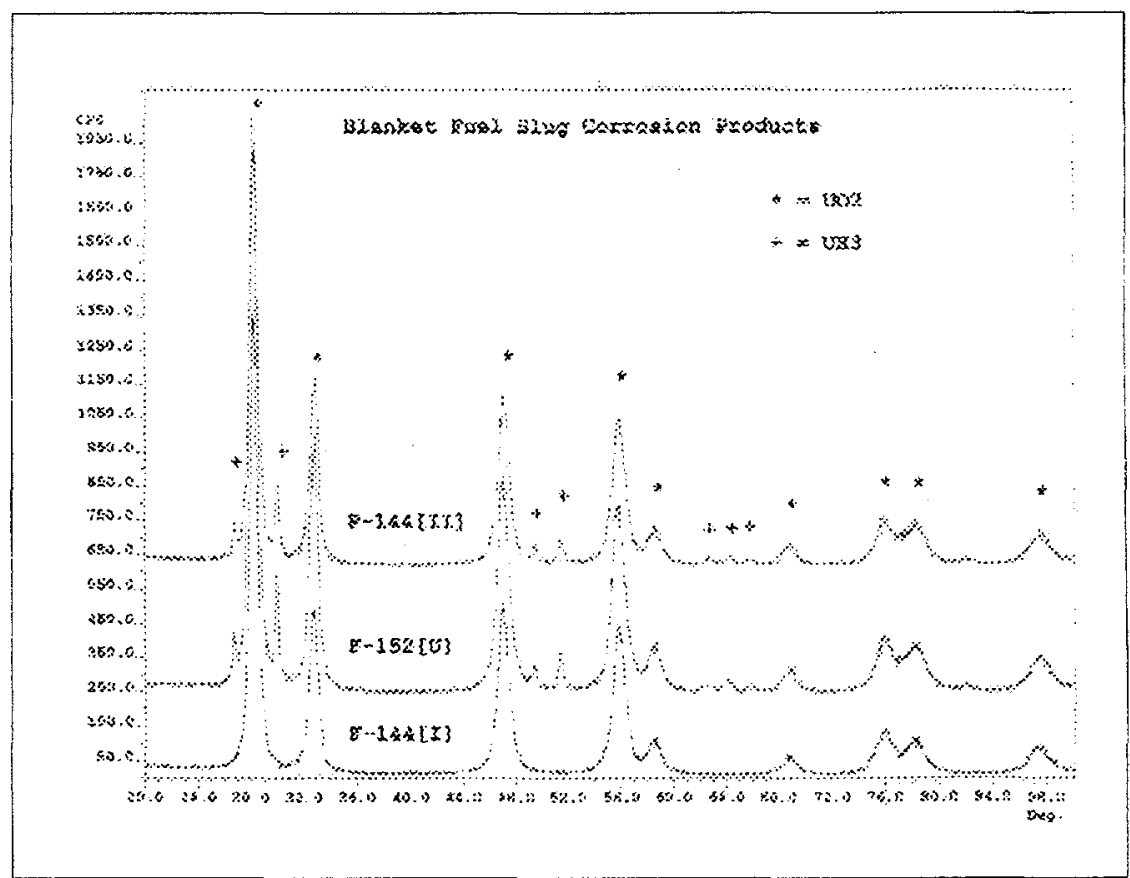

Figure 3. Superimposed XRD Patterns for the Three EBR-II Blanket Fuel Segments. *indicates the presence of $\mathrm{UO}_{2}$ and + indicates the presence of $\mathrm{UH}_{3}$. The patterns for F-144[U] show that $\mathrm{UH}_{3}$ in presents.

three sludge samples. No uranium metal peaks were observed in any of the three samples. The F-144 [I] sample showed no $\mathrm{UH}_{3}$ diffraction peaks. Incidentally, this was the sample that had completely corroded.

Table 4 shows the weight percent of both $\mathrm{UO}_{2}$ and $\mathrm{UH}_{3}$ found in the corrosion sludge of each of the three blanket fuel segments. The ratio of $\mathrm{UO}_{2} / \mathrm{UH}_{3}$ weight percent for both $\mathrm{F}$ $144[\mathrm{II}]$ and $\mathrm{F}-152[\mathrm{U}]$ was almost equivalent.

The accuracy of the results shown in Table 4 has been calculated to approximately $\pm 10 \%$ at $2 \sigma$. But, this applies only if the species is present in quantities greater than $10 \mathrm{wt} \%$. The error rises appreciably with anything less than $10 \mathrm{wt} \%$ percent The error value was determined by performing a standardless least-squares fit using data obtained from prepared mixtures containing both $\mathrm{UO}_{2}$ and $\mathrm{ZrO}_{2}$. 
Table 4. X-Ray Diffraction Data Table for EBR-II Blanket Fuel Corrosion Sludge.

\begin{tabular}{|l|c|c|}
\hline $\begin{array}{l}\text { Sample ID } \\
\text { Number }\end{array}$ & $\mathrm{Wt} \%$ of $\mathrm{UO}_{2}$ & $\mathrm{Wt} \%$ of $\mathrm{UH}_{3}$ \\
\hline \hline F-152[U] & 89 & 11 \\
F-144[I] & 100 & $\mathrm{ND}$ \\
F-144[II] & 88 & 12 \\
\hline
\end{tabular}

Figure 4 shows the back-scattered electron image of F-152[U] corrosion sludge using the SEM method. Note the size scale of the grains within the sludge. It shows that they range approximately between $5-25 \mu \mathrm{m}$ in diameter. The higher the $\mathrm{Z}$ (atomic number) of an element, the lighter the image on the micrograph. The least shaded areas in this micrograph are areas that contain uranium which has the atomic number 92 .

Figure 5 shows the energy dispersive $\mathrm{x}$-ray spectrum of the sludge which proves the

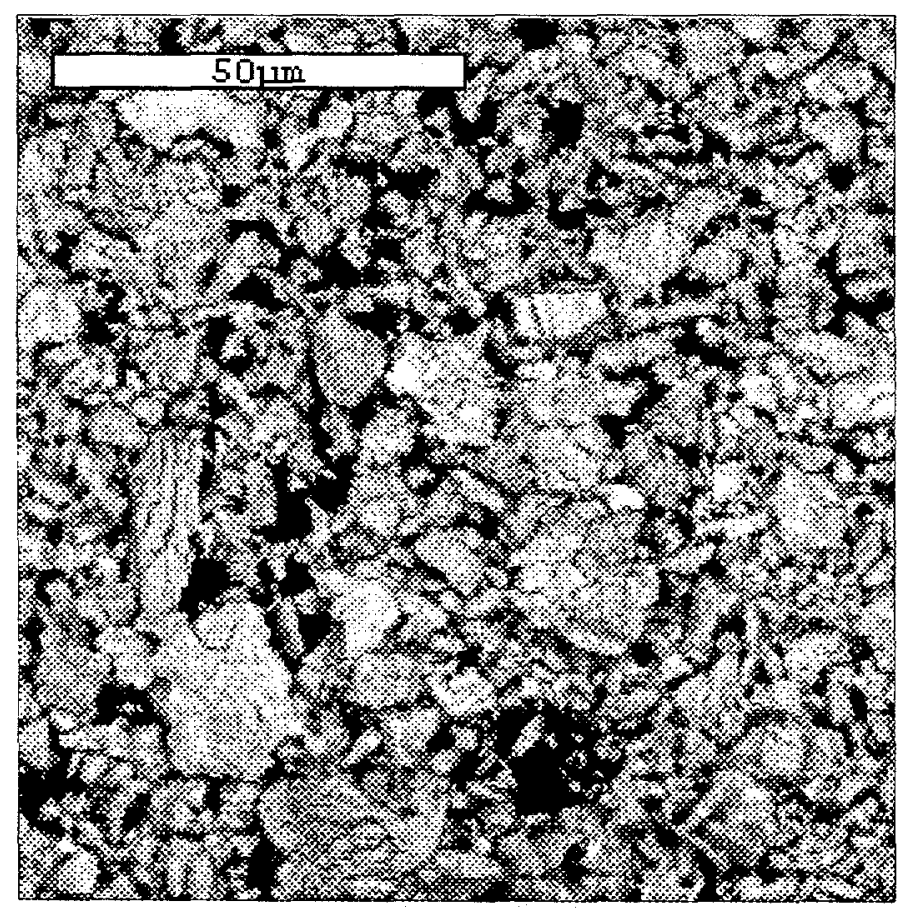

Figure 4. Back Scattered Electron Image of F-152

[U] Corrosion Sludge. 


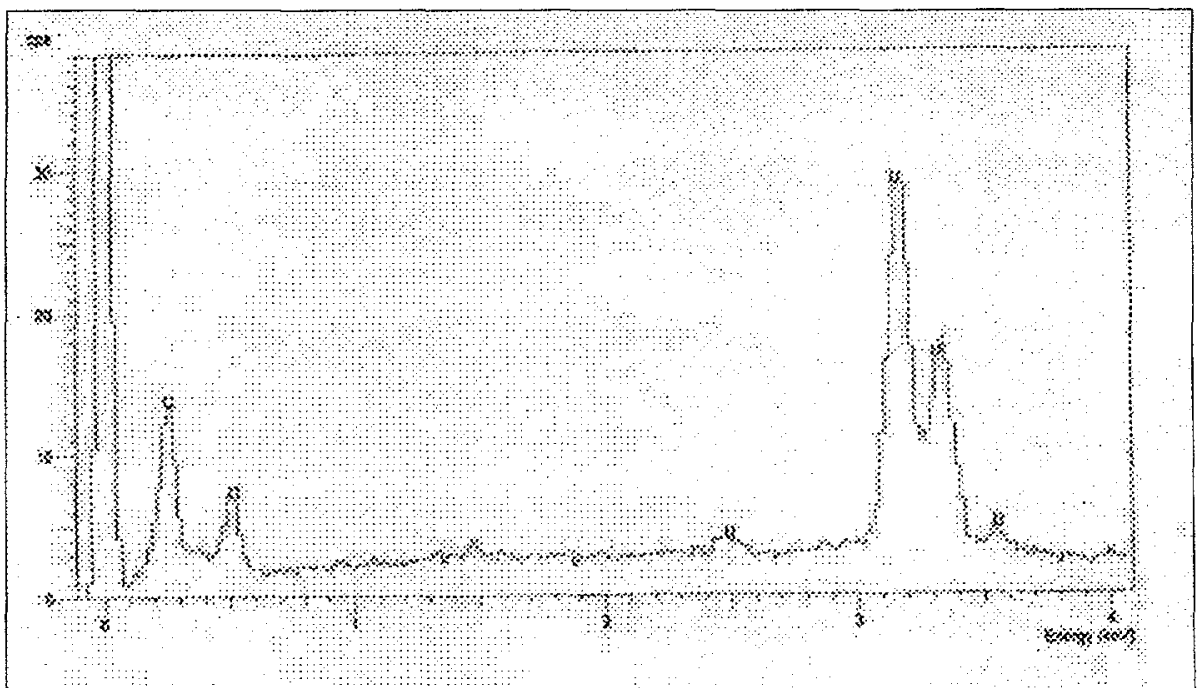

Figure 5. Energy Dispersive X-ray Spectrum of the Corrosion Sludge Belonging to F-152 [U]. Uranium and oxygen peaks can be seen. The graphite coating contributes the carbon peak.

presence of uranium and oxygen in the corrosion sludge. The carbon peak in the spectrum comes from a graphite coating. It is used to prevent excess electrical charge from building up in any one spot which would impair imaging of the sample. The carbon essentially provides a semiconducting medium that will allow electrons to disperse evenly through it. Hydrogen cannot be detected using Energy Dispersive X-ray (EDX) spectroscopy because the x-ray energy of hydrogen is too low. Therefore, this is not an analytical tool to be used for the identification of $\mathrm{UH}_{3}$ in uranium corrosion sludge.

\section{DISCUSSION}

A. Background

Before proceeding with any explanations of the phenomena observed during the blanket fuel leach test, a brief summary on uranium metal/ water interactions should be discussed to provide some clarity on the subject. Orman $[7,8]$ provided some insight into the process by which uranium metal oxidizes in water. There are several general reactions that can occur:

1. Oxidation in the presence of $\mathrm{O}_{2}$ (Oxic): 


$$
\mathrm{U}+\mathrm{O}_{2}+2 \mathrm{H}_{2} \mathrm{O} \rightarrow \mathrm{UO}_{2}+2 \mathrm{H}_{2} \mathrm{O}
$$

2. Oxidation without $\mathrm{O}_{2}$ (Anoxic):

$$
\begin{aligned}
& \text { or } \mathrm{U}+2 \mathrm{H}_{2} \mathrm{O}-\mathrm{UO}_{2}+2 \mathrm{H}_{2} \\
& 4 \mathrm{U}+4 \mathrm{H}_{2} \mathrm{O} \rightarrow 2 \mathrm{UO}_{2}+\mathrm{H}_{2}+2 \mathrm{UH}_{3} \\
& \text { and } \\
& 2 \mathrm{UH}_{3}+4 \mathrm{H}_{2} \mathrm{O} \rightarrow 2 \mathrm{UO}_{2}+7 \mathrm{H}_{2}
\end{aligned}
$$

It has been found that the oxic reaction is favored over the anoxic reaction. That is, in aerated water, uranium corrosion will proceed by reaction (1) until the oxygen is depleted. The retardation of the $\mathrm{U}+\mathrm{H}_{2} \mathrm{O}$ reaction by oxygen has been explained. [7,8] Briefly, as the uranium oxidizes via oxygen, a thin oxide layer forms. Adsorbed to the surface of this oxide layer is an additional layer of oxygen. This initially restricts the diffusion of the reactive species across this barrier thus temporarily slowing down the rate of uranium oxidation. However, when all of the oxygen is consumed, the reaction turns anoxic, the rate increases, and hydrogen gas is produced. Uranium hydride has also been found to be an intermediate product of uranium oxidation by water. $[7,8]$ One would suspect that $\mathrm{UH}_{3}$, due to its high reactivity, could not coexist with water or air. However, it has been postulated that the air/water stability of this hydride is due to protection by an adherent oxide. [7,8,9]

Gray and Einziger [6] have proposed two distinct corrosion modes for uranium metal in water using Hanford N-Reactor spent nuclear fuel (HSNF). The first mode of corrosion, Stage 1, they defined as the fuel releasing radionuclides to the water yet showing no visible corrosion or undissolved corrosion products. The second mode of corrosion, Stage 2, they defined as the fuel showing visible corrosion as well as undissolved corrosion products. They claim that Stage 2 corrosion rates were much faster than Stage 1 and suggested that the Stage 2 corrosion could have involved the faster anoxic mode of corrosion. 


\section{B. Anoxic Corrosion of The EBR II Blanket Fuel Segments}

Initially, with respect to ${ }^{137} \mathrm{Cs}$ and ${ }^{90} \mathrm{Sr}$ mass loss, the corrosion rate of the blanket fuel segments seemed moderate. However, as can be seen by the curves in Figures 1 and 2 at week 4 , both cesium and strontium levels increased substantially in the leachate belonging to sample F-144 [II]. And, on the $5^{\text {th }}$ week of sampling, the release of gas and leachate from the vessel containing F-144 [II] prevented any further sampling. The inside of the vessel was filled with a slurry, black sludge and it was impossible to distinguish any features. However, upon reexamination of the interior of the vessel after allowing the contents to settle, one could see that most of the sample remained intact.

It is difficult to explain why sample F-144 [II] behaved so anomalously with respect to F$144[\mathrm{I}]$ and F-152 [U]. Since this experiment was limited to only three samples, one cannot assume that the behavior of sample F-144 [II] was representative of rapid, anoxic corrosion of uranium metal. Yet the indication is that the anoxic process occurred to some degree because of the obvious expulsion of gas from the vessel.

As for samples F-144 [I] and F-152 [U], the same substantial release of ${ }^{137} \mathrm{Cs}$ into the leachates was observed after these vessels were left unopened in the $90^{\circ} \mathrm{C}$ oven during the final three weeks of the experiment. However, when these vessels were uncapped, there was no accompanying discharge of gas. It is not clear whether gas had evolved and leached out or if no gas had been produced. Future tests will be made to allow monitoring of the gas pressure.

Gray and Einziger [6] hypothesized that, if Stage 2 corrosion could be correlated with the Cs dissolution data that they had obtained, then Stage 2 corrosion appeared to start within the range of 9000 to $13,000 \mathrm{mg} \cdot \mathrm{m}^{-2} \cdot \mathrm{d}^{-1}$. If this hypothesis can be applied to the $\mathrm{Cs}$ dissolution rates experienced by the EBR-II Blanket Fuel segments, then sample F-144 [II] exceeded this range at the onset of the experiment. As can be seen from Figure 6, the Cs dissolution rates for F-144 [II] ranged from 34,000 to $190,000 \mathrm{mg} \cdot \mathrm{m}^{-2} \cdot \mathrm{d}^{-1}$. 


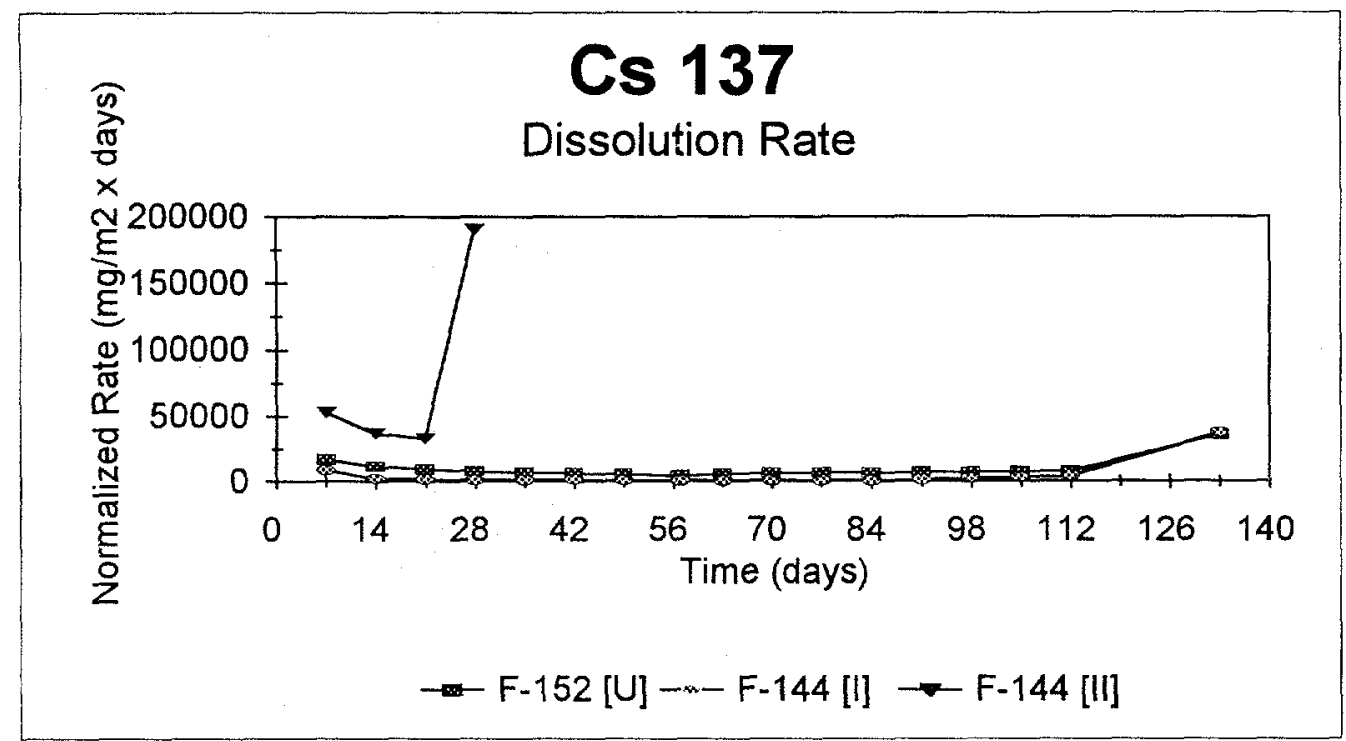

Figure 6. Cs Dissolution Rate Curves for F-144 [I], F-144 [II], and F-152 [U].

For samples F-144 [I] and F-152 [U], this range was not attained until the final sampling in week 19 (133 days). At this time, the dissolution rates exceeded the Gray Stage 2 onset range. For F-144 [I] the Cs dissolution rate was $36,000 \mathrm{mg} \cdot \mathrm{m}^{-2} \cdot \mathrm{d}^{-1}$ and for sample $\mathrm{F}-152$ [U] that rate was $38,000 \mathrm{mg} \cdot \mathrm{m}^{-2} \cdot \mathrm{d}^{-1}$. Neither of these samples Cs dissolution rates approached the rate measured for sample F-144 [II]].

\section{Strontium Carbonate Formation}

From Figure 2 and Table 2 one can see that strontium did not seem to leach out into the $\mathrm{SJ}-13$ well water as readily as cesium. There is a very probable explanation for the strontium deficient leachate. First, consider the relative solubilities of Cs vs Sr. It is known that salts of all alkali metals (Group I elements in the Periodic Chart) are considered to be soluble in aqueous solutions. Cesium is a Group I element. However, not all salts of alkaline metals (Group II elements), of which strontium is a member, are soluble in aqueous solutions. Referring back to Table 2, one can see that the SJ-13 well water contains both sodium and potassium bicarbonate. These species are readily ionizable in water. Therefore, carbonate ions were available in the leachant to precipitate with any strontium that leached out of the blanket fuel segments. Although cesium carbonate $\left(\mathrm{CsCO}_{3}\right)$ would have been fully soluble in the $\mathrm{SJ}-13$ leachant, strontium carbonate $\left(\mathrm{SrCO}_{3}\right)$ would not. The other anionic species present in the $\mathrm{SJ}-13$ water, including the 
nitrate $\left(\mathrm{NO}_{3}{ }^{-}\right)$, sulfate $\left(\mathrm{SO}_{4}^{-}\right)$, and chloride $\left(\mathrm{Cl}^{-}\right)$ions, form water soluble salts with both $\mathrm{Cs}$ and $\mathrm{Sr}$ therefore, none of these would have precipitated in the corrosion sludge.

As for strontium carbonate, consider the following equations showing its equilibrium expression and its solubility product constant:

$$
\begin{gathered}
\mathrm{SrCO}_{3}(\mathrm{~s})=\mathrm{Sr}^{2+}+\mathrm{CO}_{3}{ }^{2-} \\
K_{\mathrm{sp}}=\left[\mathrm{Sr}^{2+}\right]\left[\mathrm{CO}_{3}{ }^{2-}\right]=1 \times 10^{-10}
\end{gathered}
$$

The solubility product constant, $K_{s p}$, of $\mathrm{SrCO}_{3}$ indicates only slight solubility in water. Table 5 shows the amount of total $\mathrm{Sr}$ in each of the three samples at the onset of the corrosion testing. Although strontium masses $86,87,88,89$, and 90 were in all three samples, 88 and 90 were the only two isotopes present in sufficient quantities to have any affect on the total mass. It is apparent from Table 5 that more than enough total $\mathrm{CO}_{3}{ }^{2-}$ ions were added to each vessel to react completely with all of the strontium present. So then, the reason that the $N M L$ leaching values for strontium were so low was that most of the leached strontium was tied up as insoluble carbonate.

Table 5. Strontium and Carbonate Ion Mass Balance Data

\begin{tabular}{||c|c|c|c|}
\hline Segment ID \# & Total Sr (grams) & $\begin{array}{c}\text { Total } \mathrm{CO}_{3}{ }^{2-} \text { Added } \\
\text { (grams) }\end{array}$ & $\begin{array}{c}\text { Sr Required for Total } \\
\mathrm{CO}_{3}^{2-} \text { Added (grams) }\end{array}$ \\
\hline \hline F-152 [U] & $1.28 \times 10^{-4}$ & $1.50 \times 10^{-2}$ & $2.23 \times 10^{-2}$ \\
F-144 [I] & $4.91 \times 10^{-4}$ & $1.45 \times 10^{-2}$ & $2.15 \times 10^{-2}$ \\
F-144 [II] & $2.52 \times 10^{-4}$ & $1.57 \times 10^{-2}$ & $2.33 \times 10^{-2}$ \\
\hline
\end{tabular}

D. Uranium Hydride Formation

As seen in the XRD patterns in Figure 5, two of the three samples had formed uranium hydride $\left(\mathrm{UH}_{3}\right)$. It is known that uranium oxidation by water forms some hydride product that 
appears fairly stable in small quantities in the $\mathrm{UO}_{2}$ corrosion matrix.[7,8,9] Therefore, its presence in the F-144 [II] and F-152 [U] blanket fuel corrosion sludge is not surprising. However, its absence in sample F-144 [I] is more unexpected. Orman [7] suggested that $\mathrm{UH}_{3}$ appears to be a partial product of the uranium/water interaction but, could react further to form the products shown in reaction (4). So if $\mathrm{UH}_{3}$ had at one time been present in the corrosion product of sample F-144 [I] then it could have eventually all reacted to form $\mathrm{UO}_{2}$. And maybe this could only have occurred after all of the uranium metal had reacted. In which case, as long as metallic uranium exists in the aqueous environment, a small amount of $\mathrm{UH}_{3}$ will also coexist.

\section{CONCLUSION}

This study of the interaction of metallic EBR-II irradiated blanket fuel with SJ-13 well water at $90^{\circ} \mathrm{C}$ was conducted over a time period of six months. This study led to the destructive corrosion of the three specimens in a manner consistent with mechanisms suggested by Orman and others. $[6,7,8]$ Uranium EBR-II blanket fuels corrode readily in SJ-13 water to form a black "sludge" made up of $\mathrm{UO}_{2}$ and $\mathrm{UH}_{3}$. However, $\mathrm{UH}_{3}$ is not always present in corrosion sludge as proven by sample F-144 [I]. The possible formation of hydrogen that could have occurred in the pressure vessel containing sample F-144 [I] must be investigated in greater detail. Currently, efforts are being made to both identify and quantify hydrogen resulting from the uranium metal/water interaction using both unirradiated depleted uranium and irradiated EBR II driver fuel.

As for the fission product leach testing for ${ }^{137} \mathrm{Cs}$ and ${ }^{90} \mathrm{Sr}$, cesium appears to be more soluble in SJ-13 well water than strontium and this is probably due to the relative insolubility of $\mathrm{SrCO}_{3}$ in water. 


\section{REFERENCES}

[1] American Society for Testing and Materials (ASTM) C 1174, "Standard Practice for Prediction of the Long-Term Behavior of Materials, Including Waste Forms, Used in Engineered Barrier Systems (EBS) for Geologic Disposal of High-Level Radioactive Waste." West Conshohocken PA. pp. 14 (1991).

[2] Aa. Barkatt et al. "The Use of a Flow Test and a Flow Model in Evaluating the Durability of Various Nuclear Waste-Form Materials." Nucl. Chem. Waste Manage. 4:153-169. (1983).

[3] Aa. Barkatt, P.B. Macedo, B.C. Gibson, R. Mowad, W. Sousanpour, Al. Barkatt, M.A. Boroomand, M. Adel-Hadadi, and V.L. Rogers "The Behavior of Defense Waste Reference Glass In a Long-Term Pulsed-Flow Leach Test.” In Waste Management. pp. 471-476. (1985).

[4] A. Barkatt, P.B. Macedo, C.J. Montrose, D.D. Jackson, M.J. Apted, B.L. McVay, W.V. White, C.G. Pantano, A.B. Harker, D.E. Clark L.L. Hench. "Final Report of the Defense High-Level Waste Leaching Mechanisms Program." Pacific Northwest Laboratory.

Richland, Washington. August, 1984.

[5] American Society for Testing and Materials (ASTM) C 1220, "Standard Test Method for Static Leaching of Monolithic Waste Forms for Disposal of Radioactive Waste." West Conshohocken PA. pp. 15 (1992).

[6] W.J. Gray and R.E. Einziger. "Initial Results from Dissolution Rate Testing of N-Reactor Spent Fuel Over a Range of Potential Geologic Repository Aqueous Conditions." Pacific Northwest Laboratory. Richland, Washington. April, 1998.

[7] Orman. S. (1974): Oxidation of Uranium and Uranium Alloys. Physical Metallurgy of Uranium Alloys (J.J. Burke, ed.), Brook Hill Publishing Company, pp. 815-833.

[8] J. T. Waber. "The Corrosion Behavior of Plutonium and Uranium". Proceeding of $2^{\text {nd }}$ United Nations International Conference on Peaceful Uses of Atomic Energy. Vol. 6, pp 204-214. (1958).

[9] A.S. Newton, J.C. Warf, F.H. Spedding, O. Johnsom, R.W. Nottorf, J. A. Ayres, R. W. Fisher, and A. Kant. "Uranium Hydride - II". Nucleonics, February, 1949. 